\title{
The castorid Steneofiber from NW Germany and its implications for the taxonomy of Miocene beavers
}

\author{
Thomas Mörs and Clara Stefen \\ Acta Palaeontologica Polonica 55 (2), 2010: 189-198 doi: http://dx.doi.org/10.4202/app.2009.0013
}

Craniodental remains of a medium-sized beaver from the early middle Miocene of Hambach (MN 5) in the Lower Rhine Basin of northwestern Germany are described and assigned to Steneofiber depereti. The relatively rich material (6 mandibles and 56 isolated teeth) was collected from a single locality, Hambach 6C, and comprises specimens representing juvenile to very old individuals. This makes it possible to assess the morphologic and metric variability of a single population of Steneofiber depereti. Metrically, the mandibular tooth rows compare favorably in size to those of three subspecies described from the Loire Basin in France: Steneofiber depereti janvieri, Steneofiber d. caliodorensis, and Steneofiber d. depereti. Therefore in our opinion, division into subspecies cannot be applied to $S$. depereti in general. The difference in size between the smaller beaver from Hambach and the contemporaneous larger $S$. $d$. carnutense from the Loire Basin is remarkable. The taxonomy of early middle Miocene medium-sized castorids, referred to Steneofiber depereti, Steneofiber subpyrenaicus, and Chalicomys jaegeri is discussed. The presence of the derived beaver $C$. jaegeri in MN4 to MN6 is questioned and assignment to Steneofiber suggested. The occasional appearance of single $C$. jaegeri features in $S$. depereti supports the existence of a European lineage from the Orleanian $S$. depereti to the Vallesian $C$. jaegeri. The taxonomic status of $S$. subpyrenaicus remains unresolved.

Key words: Mammalia, Rodentia, Castoridae, morphology, systematics, Neogene, Hambach, Lower Rhine Basin.

Thomas Mörs [thomas.moers@nrm.se], Department of Palaeozoology, Swedish Museum of Natural History, P.O. Box 50007, SE-104 05

Stockholm, Sweden (corresponding author); Clara Stefen [clara.stefen@ senckenberg.de], Senckenberg Naturhistorische Sammlungen Dresden, Museum für Tierkunde, Königsbrücker Landstrasse 159, D-01109 Dresden, Germany. 
Attribution License (for details please see creativecommons.org), which permits unrestricted use, distribution, and reproduction in any medium, provided the original author and source are credited.

PoFif Full text $(609.4 \mathrm{kB})$ 